\title{
Russia in the Post-Soviet Space: Dual Citizenship as a Foreign Policy Instrument
}

Igor A. Zevelev

\author{
Igor A. Zevelev, Doctor of Science (Political Science) \\ MGIMO University (Moscow State Institute of International Relations), Russia \\ Professor \\ Kennan Institute of the Wilson Center, Washington, USA \\ Global Fellow: https://www.wilsoncenter.org/person/igor-zevelev \\ ORCID: 0000-0003-0579-2679 \\ Scopus Author ID: 6506359127 \\ ResearcherID: AAH-5983-2021 \\ Google Scholar: https://scholar.google.com/citations?hl=en\&user=0rfxYF4AAAAJ \\ E-mail: igor.zevelev@wilsoncenter.org \\ Address: One Woodrow Wilson Plaza, 1300 Pennsylvania Avenue, NW \\ Washington DC 20004, USA \\ DOI: $10.31278 / 1810-6374-2021-19-2-10-37$
}

\begin{abstract}
The spread of dual citizenship in the post-Soviet space is becoming one of the most important tools for ensuring Russia's hegemony in the region. However, this phenomenon is often overlooked in foreign policy analysis. The study of changes in Russian legislation shows that over the past three years Russia has created a legal framework that would accelerate the spread of dual citizenship in Ukraine and potentially in Belarus, Kazakhstan, and Moldova. So, Moscow gets powerful leverage, but its use has so far run into both internal constraints and concerns within the Russian government structures and the resistance of neighboring independent states. Thus, a new research field is taking shape at the
\end{abstract}


intersection of several disciplines-political science, international studies, and sociology.

Keywords: Russia, foreign policy, citizenship, post-Soviet space, Ukraine, Central and Eastern Europe.

Over the past three years, Russia has adopted laws that considerably accelerate the spread of dual citizenship in Ukraine and potentially in Belarus, Kazakhstan, and Moldova. The new Russian policy facilitating this process can significantly strengthen Moscow's influence and become one of the long-term factors cementing the post-Soviet space. What role does dual/multiple citizenship play in the modern system of international relations? How does the spread of dual citizenship in the post-Soviet space differ from similar processes in Central and Southeast Europe? Why do fundamental changes in Russian policy meet serious resistance both at home and abroad?

Russia is one of the countries whose cultural space is bigger than its national territory. Many important actors in international relations (apart from Russia there are China in East and Southeast Asia, and Iran and Turkey in the Middle East) are closely connected with millions of people who speak the same or very similar languages or are united by the same religion but live nearby in different states. Common cultural characteristics do not necessarily mean political loyalty, much less devotion of diasporas and religious communities to their "historical homeland" or "core state." However, linguistic closeness, similar religious practices, and common history facilitate contacts between people, contribute to the establishment of economic ties, and motivate temporary and constant migration. The vast majority of immigrants and seasonal workers come to Russia from neighboring countries and speak Russian. Russia ranks fourth in the world by the number of migrants (about 12 million in 2019) (International Organization for Migration, 2020, pp. 26, 88).

The cultural space shared with neighbors and high intensity of human ties allow intellectuals in "core states" to back up their spheres of geopolitical influence with the concepts of civilization or the Russian 
world, pan-Turkism or pan-Islamism, etc. This, as a rule, evokes mixed reactions from the governments of neighboring countries and strong opposition from the United States.

Russia's policy in the post-Soviet space has faced serious challenges in recent years, primarily in the culturally closest countries, such as Ukraine and Belarus. One of the main reasons for setbacks is statecentered thinking. Moscow demonstrates unwillingness to work with non-traditional actors in international relations, such as political opposition, civil society institutions, and diasporas, as well as its inability to communicate directly with the citizens of neighboring states.

In practical terms, Moscow has at least one effective policy tool that helps it to take advantage of blurred cultural and linguistic borders that do not match state borders-the attractiveness of Russian citizenship for many people living in the region. However, it is extremely difficult to estimate how many people in the post-Soviet countries would potentially want, under favorable conditions, to obtain Russian passports. Most former Soviet republics do not recognize or expressly prohibit dual citizenship with Russia. In such circumstances one can hardly expect frank answers in opinion polls. Thorough sociological studies using the methods of focus group and in-depth interviews can provide a more adequate picture, both in terms of respondents' attitude to dual citizenship and their political views. This is a big and promising research field for sociologists.

However, there is already enough evidence that millions of people have or seek to obtain a Russian passport as a second one, without necessarily planning to move to Russia for permanent residence. The new amendments to the Russian citizenship law, adopted in 2020, are designed to become one of the most important tools for strengthening Russian influence in the post-Soviet space. The accelerating spread of Russian passports in neighboring countries, especially in Ukraine, will increasingly affect their internal demographic, economic, social, and political development. Actions taken by public authorities, starting with the adoption of relevant citizenship laws, cause a chain reaction, including changes in the individual life strategies of millions of people, which, in turn, affects domestic and world politics. 
The dual citizenship theory has been mostly explored in jurisprudence and political sociology, as well as in international migration studies (Spiro, 2008, 2016; Joppke, 2010). Political aspects of dual citizenship in the post-Soviet space are analyzed in the works of Oxana Shevel, Irina Molodikova, Eleanor Knott, and Ramesh Ganohariti (Shevel, 2009, 2012, 2017; Molodikova, 2017; Knott, 2018; Ganohariti, 2020). This article takes just the first step in understanding this phenomenon from the point of view of Russian foreign policy by studying rather radical changes in Russian citizenship acquisition in the context of global and regional trends. The main goal of the article is outlining a new area of research at the intersection of political science, international relations, and sociology, namely the study of post-Soviet transborder citizenship.

\section{GLOBAL PHENOMENON}

We are witnessing a "grand transformation of citizenship" (Shachar, 2020). Until the end of the last century, citizenship was acquired almost exclusively by birth: the term 'birth lottery' is widely used in the literature on social inequality which is secured by citizenship in countries with different levels of well-being (Shachar, 2009). It was possible to change citizenship only if a person moved and made his or her home in another country or if borders were moved and a territory and its population fell under another jurisdiction. Pursuing their own interests, states sought to make citizenship central to the identity of their nationals, for which reason they mythologized it as much as possible. Dimitry Kochenov claims that citizenship is "a traditionally violent and ultimately totalitarian status originating in the pre-modern era... Citizenship is a relic of a world where there were no ideals of equality and justice" (Kochenov, 2021).

Today, citizenship is turning into a flexible and dynamic status, which is not necessarily tightly linked to national territory, and is more and more often chosen freely and pragmatically by those who can afford it (Ong, 1999; Milanovich, 2016; Harpaz, 2019). As a result, $\mathrm{dual} /$ multiple citizenship becomes increasingly popular. At the same time, there is no credible statistics regarding the number of people with 
multiple citizenship in the world. For example, the United States keeps no such record, although the Supreme Court lifted the ban on multiple citizenship as far back as 1967. All people with dual citizenship in the United States are simply considered Americans, and acquisition of a second passport is one's personal choice.

In the 21st century, second citizenship does not require its holder to give up the previous one, it is less often associated with a permanent move and it usually elevates one's social status by creating additional opportunities and becoming a "global asset" of a sovereign individual. It is also a secure asset that is passed on to the next generation (Harpaz, 2019, pp. 2, 126-152). Nation-states gradually stop resisting this practice: the share of countries where citizenship is automatically lost upon acquisition of another citizenship fell from 63\% in 1960 to $24 \%$ in 2020 (van der Baaren, 2020; Vink et al., 2020).

Until the end of the Cold War, many states demanded unconditional loyalty from their citizens, particularly their readiness to serve in the military. National identity was designed in such a way that a citizen was expected to be prepared to give his or her life for the country, if necessary. Today we can talk about the rapid desacralization of citizenship. With the transition to professional armed forces and the abolition of conscription, the increasing number of intermarriages between citizens of different states, the acceleration of international migration, and greater interdependence, other considerations have begun to prevail. Respect for the individual's personal choice, the desire to win political support among immigrants, and the increasingly growing influence of diasporic organizations have become major factors boosting tolerance for multiple citizenship in Western countries. In Turkey (since 1981) and Mexico (since 1998), decisions to strengthen ties with expats by preserving their citizenship of the country of origin were dictated by other reasons, particularly by the desire to receive money transfers from them and expand the tax base (Joppke, 2003, p. 442).

Other factors explain the emergence of dual citizenship in Central and Southeast Europe. After the end of the Cold War, "non-resident ethnic citizenship" became widespread there. 
Countries that had lost territories inhabited by ethnically identical groups began an active campaign to issue passports without requiring new citizens to move to their "historical homeland." The relevant laws were adopted in Croatia and Romania in 1991, in Bulgaria in 2001, in Serbia 2004, and in Hungary, at the second attempt, in 20102011. As a result, these states started turning into subregional centers, attracting many people living in neighboring countries. As a rule, the spread of this kind of dual citizenship became possible due to the implementation of distinct national identity projects designed to compensate for the sense of historical defeat and loss of territories and population. Whereas in Western Europe and the United States dual citizenship is often promoted by left-wing and center-left forces seeking to include migrants from developing countries in the political system of their new homeland, in the east of the continent, it is mainly rightwing nationalist parties that recruit new citizens from among diaspora members (Joppke, 2003; Waterbury, 2014, pp. 36-49).

The philosophy of "non-resident ethnic citizenship" rests on a paradoxical combination of the traditional nativist approach based on the principles of ethnic kinship, and a postmodern view allowing multiple, dynamic, and situational identity of the individual. At the same time, many countries are trying to disguise its ethnic component. For example, in an effort to mitigate the negative reaction of the European Union (EU) and neighboring countries accusing the Viktor Orban government of ethno-national revisionism and the implementation of an ambitious plan to unite all Hungarians in one state, Budapest approved only two criteria for acquiring citizenship: direct descent from a Hungarian citizen and command of the language. Neither nationality, nor residence in Hungary, nor the termination of another citizenship is required. However, it is clear that if not the letter, then the spirit of Hungarian and other similar laws in Central and Southeast Europe links ethnicity to citizenship and separates both of them from residence, that is, from territory.

"Non-resident ethnic citizenship" is essentially the opposite of repatriation that encourages people to return to their historical homeland (Germany, Israel, Kazakhstan, as well as Russia, albeit with 
less success) (Zeveleva, 2013). However, such state programs cannot foresee and fully control the behavior of individuals. At the level of individual citizens and families, "non-resident ethnic citizenship" can smoothly turn into repatriation and vice versa. For example, having received a second passport, in a few years' time a person may decide to move, that is, to repatriate. Repatriates, on the contrary, often go back to the country of origin, thus becoming "non-resident ethnic citizens."

By making members of diasporas "non-resident ethnic citizens," Central and Southeastern European governments usually pursue at least one of the following four objectives: get some sort of compensation for the national trauma from the loss of territories by maintaining contact with people who live on these territories; strengthen political influence in the region; change the country's ethnic balance by increasing the dominance of the main ethnic group; or secure political support among new citizens for nationalist forces. In the 2014 election, 95\% of Hungarians living in neighboring countries voted for Viktor Orban and his Fidesz party (Republikon Institute, 2014).

The successful implementation of programs promoting "nonresident ethnic citizenship" requires three conditions: political will and a well-organized passportization system in the "core state," a significant number of people in neighboring countries who wish to voluntarily acquire dual citizenship, and the lack of active resistance from the governments of countries where such people live.

In most cases the policy of "non-resident ethnic citizenship" is aimed at those neighboring countries that are less developed economically and weak politically. Croatia pursues such policy with regard to ethnic Croats in Bosnia and Herzegovina, Romania targets citizens of Moldova, Bulgaria aims at North Macedonia, Serbia’s policy covers Bosnia and Herzegovina and Montenegro, and Hungary directs its efforts at Romania, Serbia, Ukraine, and Slovakia. The latter is the only country that put up strong resistance to the "non-resident ethnic citizenship" approach by instantly responding to the Hungarian law with its own legislation adopted in the same year 2010, which denationalized anyone who had applied for a second passport (Arriaza, 2015, pp. 114-135). 
Hungary carries out the most ambitious program to promote its "non-resident ethnic citizenship" project. Out of three million ethnic Hungarians living in neighboring states, about one million have already received a Hungarian passport, having become persons with dual citizenship. Public authorities set target indicators for transborder citizenry and encourage their consulates and other government officials to work towards their implementation.

Israeli sociologist Yossi Harpaz has analyzed ample empirical material to show that global inequality in the value of citizenship of different countries is the main factor prompting people to obtain a second passport. For example, less than $2 \%$ of Americans eligible for Hungarian citizenship have used the chance, while a similar indicator is $30 \%$ in Romania, 61\% in Serbia, and 96\% in Ukraine (Harpaz, 2019, pp. $15,33,45)$. The inverse correlation of these indicators with the global status of the first citizenship is obvious.

So, the reasons why more and more countries believe that the proliferation of dual/multiple citizenship may serve, or at least does not contradict, their interests are quite different. These include attempts to provide political support for immigrants, ensure remittance flows, and increase the influence of the state in the region. However, there is enough evidence that the opportunities offered by dual citizenship are not always used by individuals as it was initially intended by the governments. For example, many ethnic Serbs in Vojvodina (an autonomous province of Serbia) started to learn Hungarian in order to obtain EU citizenship by taking advantage of the law adopted in Hungary in 2011 and intended for ethnic Hungarians (Harpaz, 2019, pp. 39-66).

The spread of dual/multiple citizenship in many regions of the world is yet another manifestation of the ongoing globalization, increasing international migration (in 2019 alone there were 272 million migrants in the world), the rise of intermarriage, and the growing number and soaring political importance of transnational communities, including diasporas (International Organization for Migration, 2020, p. 3). Proliferation of dual citizenship in the postSoviet space is a special case. 


\section{RUSSIA: THREE PERIODS}

For nearly thirty years after the disintegration of the Soviet Union Russia has been looking for its own model of dual citizenship policy in the post-Soviet space. During this time strategy underwent significant changes at least twice, the most radical one quite recently, in 2020. Just like Croatia and Romania, in the early 1990s Russia led the way in promoting dual citizenship for the residents of neighboring countries. Because of its special role in the region, Russia's policy could have had much bigger geopolitical consequences. However, from 1993 to 2007 Moscow's efforts on this track were extremely inconsistent and brought very modest results. It seemed that Moscow had become disappointed at the possibility and expediency of promoting dual citizenship in the post-Soviet space. In 2008-2017, it became quite difficult to acquire a Russian passport as a second one. However, in 2017-2020, unexpectedly for many, Moscow got back to this idea and adopted a number of major amendments to the citizenship law which opened up prospects for a significant number of people in the countries vital for Russia's national interests-Ukraine, Belarus, Kazakhstan, and also Moldova-to obtain dual non-resident citizenship.

The multi-layered and competitive intellectual environment, combined with the carefully guarded processes of political and administrative decision-making, explains why Moscow's actions regarding dual citizenship have so far been inconsistent and hardly predictable. The perception of citizenship is intertwined with Russian national identity, which is understood in a variety of ways. Russia is not unique in this regard: Christian Joppke was one of the first experts to suggest analyzing the formation of citizenship as a political process connected with the construction of ethnic identity, believing that this approach is applicable to most countries of the world (Joppke, 2003). The contradictory nature of Russian citizenship policy is largely attributed to the elite conflicts. Based on Graham Allison's analysis of bureaucratic politics, John Ikenberry describes groups fighting to advance their administrative decisions in the government as "epistemic communities of well-placed government specialists and intellectuals who form distinct schools of foreign policy thought" (Allison, 1969, pp. 689-718; Ikenberry, 1993, pp. 57-86). 
Discussions about granting Russian citizenship to millions of citizens of former Soviet republics began almost immediately after the collapse of the Soviet Union and are still going on. In order to get a better idea of the origins, specific features and significance of contemporary dual citizenship policies in the post-Soviet space, it would be useful to briefly outline the evolution of Moscow's approaches in the previous periods (Zevelev, 2008).

\section{3-2007}

Since 1993, the Russian government had been regarding the protection of the rights of compatriots in neighboring countries as the main strategic foreign policy objective, and dual citizenship as the main tool for achieving this objective. Moscow saw three advantages of dual citizenship over the repatriation of ethnic Russians demanded by some nationalists. Firstly, this approach looked more "civilized" (a favorite word of the political elite in the early 1990s) than establishing a "special relationship" with ethnic Russians abroad. The emphasis was placed on the civil, not ethnic, nature of Russia's policies. As then Russian Foreign Minister Andrei Kozyrev wrote in his memoirs: "We cannot take the ethnic factor as a basis of our policy. This would lead to ethnic conflicts, as was the case in Yugoslavia" (Kozyrev, 1995, p. 98).

The second advantage of dual citizenship was that it supposedly could stop the uncontrolled influx of immigrants into Russia, giving them at least some security and peace of mind in the country of permanent residence. Amid the devastating economic crisis in the 1990s, the government believed that the accommodation of newcomers would require huge expenses, which Russia could not afford at the time.

The third advantage of dual citizenship was connected with the special role Russia played in the region. Dual citizenship could serve as a convenient and effective instrument for keeping the post-Soviet states in Moscow's orbit. Russia assumed that the protection of its citizens abroad by a global or regional power was not a rare practice. This policy was often pursued by the United States in Latin America and by France in Africa. If Russia had had millions of its citizens in 
neighboring states, it would have been difficult to prevent its absolute and unrestricted dominance in the former Soviet Union.

Russian diplomacy initially refrained from unilateral actions and preferred to conclude bilateral agreements. However, Moscow faced fierce resistance from the governments of almost all of the other postSoviet states as they feared that this would jeopardize their nationbuilding. Citizenship plays an important role in forming a new identity for young states, and their leaders did not want to allow a situation where their citizens would simultaneously be citizens of a neighboring state. They regarded Russia's intention to introduce dual citizenship, albeit through relevant treaties, as an attempt to create an instrument of influence under the guise of concern about compatriots.

Bilateral negotiations in 1993-1995 were largely fruitless. The only results of the attempts to use this "essential tool" for achieving the "main strategic foreign policy objective" were agreements with Turkmenistan signed in December 1993 and with Tajikistan signed in September 1995 (Agreement, 1994; Treaty, 1996). Turkmenistan unilaterally withdrew from the agreement with Russia in 2003. In 2007, two more post-Soviet countries-Kyrgyzstan and Armenia-adopted laws allowing dual citizenship. In addition, Russian passports were issued to almost all residents of Abkhazia and South Ossetia (even before the events of 2008), as well as many residents of Transnistria.

In 1995, it became clear that Russia's dual citizenship policy in countries that were most important for it had failed. Three quarters of ethnic Russians from the former Soviet Union live in Ukraine, Belarus, and Kazakhstan. The lack of results at negotiations with these three countries essentially meant the failure of the Russian strategy to institutionalize dual citizenship in the post-Soviet space.

Failed negotiations with Ukraine were particularly painful for Russia. Despite his promises during the 1994 election campaign, President Leonid Kuchma took a tough stance against dual citizenship. This issue became one of the stumbling blocks that until May $1997 \mathrm{did}$ not allow the two countries to sign a comprehensive bilateral treaty. As a result, the Treaty of Friendship, Cooperation and Partnership between the Russian Federation and Ukraine did not contain a single provision 
mentioning dual citizenship, thus indicating a serious concession by Russia compared to its position before 1995 (Treaty, 1999).

As a result, by 1995, de jure dual citizenship in the post-Soviet countries, which had been proclaimed a strategic objective of the Russian foreign policy, began to gradually disappear from the political and diplomatic agenda as a matter of bilateral or multilateral relations. Despite serious efforts undertaken by diplomats, a very important tool of Russian politics was not formalized in international treaties. Faced with stubborn opposition from other governments, Moscow simply backed off.

The issue of dual citizenship unexpectedly resurfaced in 2004. Seeking to attract pro-Russian voters during the Ukrainian elections in 2004, Leonid Kuchma and Victor Yanukovich agreed to work out a dual citizenship agreement with Russia. However, it was not quite clear whether the Verkhovna Rada would ratify such an agreement and whether Yanukovich would be consistent enough in pursuing the matter. Nevertheless, Russian federal agencies started to draft the treaty, but the Orange Revolution botched all plans. The revival of the idea of dual citizenship in 2004 indicated that Russia was ready to address this issue again under favorable conditions. The resistance of neighboring states was the main reason why it was removed from the agenda. First Deputy Prime Minister Dmitry Medvedev said in December 2006: “As for the introduction of dual citizenship, the international practice of recent decades rejects this institution." But he hurried to add that the question of dual citizenship in the CIS could come back on the agenda when the level of integration would reach that in the European Union (Dmitriev, 2006). And yet, the barely controllable process of obtaining dual citizenship in the post-Soviet space went on.

\section{8-2017}

In 2008-2017, the dominant positions in the internal bureaucratic struggle around dual citizenship were held by those who opposed easy acquisition of Russian passports by residents of neighboring countries. According to this part of the bureaucratic apparatus, Russia had to strengthen the state and its institutions within its own national borders. 
Law enforcement and security agencies agreed with this view. They claimed that it would be virtually impossible to run background checks on newly arriving citizens. In addition, the rapid spread of Russian citizenship outside Russia could jeopardize state instruments of control. There were also many fears that the liberal citizenship law would further open the door to Russia for Central Asians and thereby increase the threat of terrorism from neighboring Afghanistan. The Ministry of Internal Affairs set up numerous bureaucratic obstacles to prevent easy access to Russian citizenship. And yet, despite these difficulties, almost three million people received Russian passports from 1992 to 2002, and another 3.3 million in 2014-2017 (Gulina, 2020).

The Russian Citizenship Law of 2002 introduced a serious restriction that prevented further spread of dual citizenship: Article 13 required applicants for a Russian passport to give up the citizenship of another state (Law, 2002). The provisions of the law, which seriously limited the spread of dual citizenship and complicated the acquisition of a Russian passport, entered into force in 2007. It seemed that Russia drew the line.

By that time dual citizenship had become popular only in small countries and territories that were completely dependent on Russia economically and where Russia maintained its military presence: Tajikistan, Kyrgyzstan, Armenia, Abkhazia, South Ossetia, and Transnistria. Besides, about 100,000 Russians lived in Latvia and Estonia, but most of them did not have dual citizenship, even though they would have preferred it.

This could hardly be called "non-resident ethnic citizenship," since the share of ethnic Russians (with the exception of Transnistria, albeit with some reservations) in those countries was extremely small. The total number of persons in these countries who hold a Russian passport as a second one can be estimated at about one and a half million. In the whole of the post-Soviet space, by 2019-2020, the total number of persons with de facto dual citizenship, who were not at all eager to report this to the authorities of their home countries, had exceeded two million. This is less than $1.5 \%$ of Russia's population (for comparison, this figure is about $10 \%$ in Hungary). 
Until 2017, Russia's citizenship laws, repatriation program and migration policy did not distinguish between ethnic Russians, Russianspeaking people and East Slavs, on the one hand, and members of other ethnic groups, on the other. Until 2020, when Russia began an active campaign to issue passports to residents of Eastern Ukraine, the absolute majority of persons with two passports in the post-Soviet space were not ethnic Russians. This evoked resistance in the Russian government agencies which opposed further spread of dual citizenship. A certain part of the Russian elite found this policy inconsistent and even absurd. Mikhail Remizov, a prominent and influential author and political strategist, complained: "Russians outside the Russian Federation have been deprived of any advantages in obtaining its citizenship, and have not been covered by its diasporic and resettlement policy" (Remizov, 2016, p. 11).

\section{7-2020}

In 2017-2020, a number of important amendments to the citizenship law were adopted. They did not explicitly offer any advantages to ethnic Russians or East Slavs, but essentially established a fast-track passport acquisition procedure for them. Russia basically followed in the footsteps of Hungary, which by 2011 had created a system of preferences for ethnic Hungarians in neighboring countries, while avoiding open ethno-nationalist justification of its policy. A liberal approach to citizenship is supported by fairly large groups within the Russian elite: the "imperialists," who see dual citizenship as an effective tool of Moscow's regional domination; Communist Party members who are still nostalgic for the ideals of Soviet-era "friendship of peoples," which in most cases go hand in hand with ethno-nationalist motives (Zyuganov, 2020); the so-called economic bloc in the executive branch, which, like many liberal economists, insists that the Russian economy needs an influx of low-cost labor with a good command of the Russian language (President of Russia, 2018).

This broad and diverse coalition gained the upper hand in 2017, when the Kremlin became increasingly aware of the fact that it was impossible to bring Ukraine back into its sphere of influence by 
previous methods, Kazakhstan and Belarus were seeking to pursue a "multi-vector" foreign policy, and European orientation was gaining popularity in Moldova. So the Kremlin agreed to drastic changes in legislation and offered a fast-track procedure for the acquisition of Russian citizenship by millions of citizens in key post-Soviet countries.

In 2017-2020, the Federal Assembly, prompted by the Kremlin, adopted three sets of amendments to the citizenship law. This meant a radical revision of Russia's policy in the post-Soviet space, primarily with regard to Ukraine, Belarus, Kazakhstan, and Moldova (Zevelev, 2020).

Firstly, in 2017, citizens of Ukraine acquired a special status in Russian legislation. It no longer required documents confirming the consent of the Ukrainian government to the termination of Ukrainian citizenship as a condition for obtaining Russian citizenship. From then on, a copy of an application for abandoning Ukrainian citizenship was enough (Law, 2017).

Secondly, in 2019, Russian legislation was amended to specify the categories of individuals entitled to fast-track naturalization. On Putin's instructions, this status was initially awarded to residents of the unrecognized Donetsk and Lugansk People's Republics (DNR and LNR). Later, Putin granted this right to everyone who lived in the Donetsk and Lugansk regions of Ukraine, which are geographically larger than the "people's republics" (President of Russia, 2019b; Decree, 2019). As a result, about seven million people became eligible to acquire Russian citizenship easily and quickly. So, in 2017-2019, the Kremlin basically introduced a special Russian citizenship regime in certain parts of Ukraine. At the same time, many residents of the unrecognized DNR and LNR republics, just like two million Crimeans back in 2014, became persons with dual citizenship, since from the point of view of Ukrainian legislation they did not forfeit Ukrainian citizenship.

Thirdly, in April 2020, a new package of amendments to the citizenship law simplified the application procedure for all citizens of Ukraine, as well as Belarus, Kazakhstan, and Moldova. The provision requiring five years of continuous residence in Russia was abolished. In most cases, the time needed for obtaining citizenship was reduced to 
one year. What is crucial is that the latest amendments to the law allow a person to apply for a Russian passport without losing the citizenship of another country (Law, 2020). The amendments entered into force on July 24, 2020.

Citizens of Ukraine were the first to grab the opportunities offered by the aforementioned legislative measures. They firmly hold first place by the number of obtained Russian passports: in 2020 they made up 410,000, or $63 \%$ of all new citizens (Migration, 2020). Russian citizenship is much less attractive in Belarus and Kazakhstan than in Ukraine: agreements concluded within the Eurasian Economic Union (EAEU) and the Union State with Belarus provide for free movement of labor. However, they do not allow permanent residence in another country without a work contract, which in some cases may become an issue (Pirker and Entin, 2020). The prospect of obtaining a Russian passport appears to be attractive for only small groups of population in Belarus and Kazakhstan (these are mainly ethnic Russians in Kazakhstan as well as political oppositionists and activists). For many Moldovans, the possibility of obtaining a Romanian passport looks more attractive than Russian citizenship, although the latter may be of interest to some seasonal workers.

The main targets of the new legislation are two groups of citizens of Ukraine, as well as Belarus, Kazakhstan, and, to a lesser extent, Moldova. Each of these groups potentially includes several million people. The first category is made up of those who plan to move to Russia for permanent residence. The Kremlin understands that the country is facing serious demographic problems, especially in Siberia and the Far East. The concept of state migration policy for 2019-2025 clearly states that attracting foreigners and migrants for resettlement in these areas is a priority (President of Russia, 2018). At first glance, these changes in the citizenship policy reflect the position of the "economic bloc" in the government and are intended to inspire a new migration policy in Russia. However, the president is counting on the support of other segments of Russian society as well. In December 2019, Putin explained which foreigners he would like to come to Russia: "Of course, it is easier for people who know and respect Russian culture and who 
speak Russian to adapt to the situation in Russia. This is why it is easier, for example, for Belarusians, Ukrainians, and Moldovans, because it is just simpler for them. And the locals take it easier. There are three million Ukrainians living in Russia, and almost the same number came after the tragic events in Donbass. It is more difficult to adapt for people, say, from Central Asia” (President of Russia, 2019c).

The second category includes those who will remain residents of Ukraine or the three other countries, but, nevertheless, will obtain Russian citizenship. Technically, the amendments of 2020 apply only after a person has moved to Russia. Chairman of the State Duma Committee on the Commonwealth of Independent States Affairs, Eurasian Integration and Relations with Compatriots Leonid Kalashnikov (Communist Party) and his first deputy Konstantin Zatulin (United Russia) have vigorously supported the lifting of the provision requiring a person to move to Russia in order to obtain citizenship. In April 2020, together with Kazbek Taysaev (Communist Party), they tried to include the relevant amendment in the law, but the executive branch balked (Bill, 2020; Yakunin, 2020). In practice, however, the removal of the provision requiring the termination of original citizenship would encourage many people to have a domicile in two countries.

Ukraine's President-elect Vladimir Zelensky responded to Putin's plan to simplify the procedure for granting Russian citizenship to citizens of Ukraine by posting a statement on Facebook in April 2019. He promised to grant Ukrainian citizenship to persons of all countries who suffered from authoritarian and corrupt regimes, but above all, to "Russians who suffer probably the most today" (Zelensky, 2019). In August, Zelensky signed a decree that simplified the process of obtaining Ukrainian citizenship for "Russian citizens persecuted for political reasons" (Moscow Times, 2019). Vladimir Putin replied by saying: "I have said on many occasions that Ukrainians and Russians are fraternal peoples. And even more: I think this is actually one people with its specific features-cultural, linguistic and historical-but in essence it is a single people. And if we have common citizenship, both Russians and Ukrainians would only gain: we will be stronger and 
more efficient... If Ukraine begins issuing passports to Russian citizens and we in Russia issue passports and grant citizenship to Ukrainians, then sooner or later we will inevitably come to the expected result: everybody will have single citizenship. This must be welcomed" (President of Russia, 2019a).

In 2021, the Ukrainian government has become firmly determined to prevent dual citizenship with Russia. Work is underway to draft a bill that will completely exclude any possibility of holding both a Ukrainian and a Russian passport at the same time. Previous attempts to introduce penalty for dual citizenship failed. The last such attempt was made in May 2020, but the Verkhovna Rada refused to consider the bill proposed by the president. In February 2021, Ukraine's National Security and Defense Council (NSDC) announced that the government would develop a mechanism for identifying dual/multiple citizenship, primarily among Ukrainians who apply for elected or high-ranking positions. Drawing on the experience of the Baltic countries, Ukraine plans to allow dual citizenship with the EU countries and a number of other states, but not with Russia. According to the NSDC's decision, the government should begin an interstate dialogue on the conclusion of bilateral agreements on dual citizenship with interested countries, except for the "aggressor state," that is, Russia. There is another draft law currently under discussion which will introduce prison terms of two to five years for any citizen of Ukraine who conceals his or her Russian passport (Kommersant, 2021; TASS, 2021).

Nevertheless, there is every reason to believe that a sufficiently large number of people in Ukraine and the three other post-Soviet states will use the opportunity of dual citizenship and end up living in two countries. Until now, none of Kiev's attempts to prevent dual citizenship has been successful. The experience of Central and Southeast Europe (Croatia, Hungary, Serbia, and Romania) shows that citizens of lowincome countries seek employment, education and medical care in neighboring higher-income countries, and dual citizenship simplifies and accelerates all procedures and allows them to maintain close ties with their homeland. This may have serious political consequences. For example, persons with dual, Ukrainian and Russian, citizenship 
would most likely want labor migration to be simple and easy, and therefore would probably prefer to vote for those politicians in Ukraine who promise a "constructive" policy towards Moscow. This group of Ukrainian citizens can become an instrument of Russia's influence on the neighboring state.

While talking about "one people" and simplifying and accelerating the procedure for obtaining Russian passports for many categories of citizens in the post-Soviet space, the Kremlin in December 2020 initiated new legislative restrictions for persons with dual citizenship. This is in line with the tough stance assumed in 2014, when all Russian citizens permanently residing in Russia and holding another citizenship or a residence permit of another country were required to notify the Ministry of Internal Affairs thereof (Law, 2014). The new package of restrictions submitted by the president to the State Duma in 2020 prohibits such persons from holding many federal, regional and even municipal positions as well as from working in security and law enforcement agencies (State Duma, 2020). The attitude of the state towards persons with dual citizenship was ironically formulated by the presidential representative in the State Duma, Garry Minkh. "Be so kind and make up your mind as to which state you serve," he addressed the potential "targets" of the bill. "Because the servant of two masters is a famous character, but he is also a little comedic..." (Zamakhina, 2021).

Apparently, the security forces standing behind this legislative initiative balanced what they think is an overly liberal approach to dual citizenship, which served as the basis for the legislative amendments adopted in 2017-2020. From the point of view of modern international standards, measures limiting the rights of persons with dual citizenship, including a ban on holding certain positions in the government, are illegal, as they violate human rights (Spiro, 2010).

In the future, further promotion of dual citizenship, as a convenient foreign policy tool in the post-Soviet space, will face continuous resistance from the security forces which are quite suspicious of Russians living in the country with two passports. Mass "non-resident ethnic citizenship" projects in many parts of 
the world are temporary, flexible and depend on changing political circumstances, and Russia will not be an exception (Brubaker and Kim, 2017; Waterbury, 2014).

\section{GEOPOLITICAL IMPLICATIONS: THREE SCENARIOS}

Over the past three years, Russia has adopted laws that significantly accelerate the spread of dual citizenship in Ukraine and potentially in Belarus, Kazakhstan, and Moldova. Like in some Central and Southeastern European countries, the new Russian policy is designed to strengthen political influence in the region and compensate for the territorial losses by maintaining ties with people living in the newly independent states. There are quite a few people in the post-Soviet space who would like to become Russian citizens, but many of them would prefer to keep their current passports as well. There is not yet a system of organized passportization of residents of neighboring countries (with the exception of the unrecognized Donetsk and Lugansk People's Republics), but Russia has already created legislative prerequisites for that. There is no doubt that the governments of neighboring countries will soon start taking new measures to make it difficult for their citizens to obtain Russian passports.

Keeping the post-Soviet space as Moscow's exclusive zone of influence is the Kremlin's strategic goal. Transnational citizenship may eventually become one of the main tools for ensuring Russia's hegemony in the region. In fact, instead of redrawing the borders again, it can use softer measures to influence the identity of people living in neighboring countries and their sense of belonging (Waterbury, 2014, p. 38; Kivisto, 2007, p. 286). Russia's ability to engage with citizens and compatriots in the post-Soviet states, especially those located west of Russia, may become one of the key instruments of its policy in the region in the coming years. The governments of the post-Soviet countries regard such a policy as "passport aggression" on the part of Russia, even though many of their citizens would like to have two passports. The rapid spread of Russian citizenship in Ukraine, and possibly in Belarus, Kazakhstan, and Moldova, may call into question the sovereignty of these countries (Melvin, 2020). 
Three scenarios may be sketched out for the possible direction of the dual citizenship situation in the post-Soviet space in the coming decade. These scenarios are not mutually exclusive.

Under the first scenario, if the post-Soviet space completely falls apart and its separate parts get incorporated into other regional systems forming around the West, China, and Turkey, the attractiveness of Russian citizenship will decrease. European countries are unlikely to want to include countries with a large number of Russian passport holders in their institutions, which will encourage the governments of the former Soviet republics to resolutely block further spread of dual citizenship. It will not be easy to do. The very existence of dual citizenship will slow down the disintegration of the post-Soviet space.

The second scenario envisions turning the region into a system with a clearly defined center surrounded by close and distant neighboring countries. In this case, citizens of post-Soviet states would prefer dual citizenship to be freely available. However, under this scenario, too, the governments will try to limit the spread of dual citizenship, fearing the loss of sovereignty. Some elements of this scenario already exist today, and dual citizenship can become an additional factor that will keep the system from falling apart completely and developing by the first scenario.

Finally, the third scenario envisages the transformation of the post-Soviet space into a community where states cede more and more functions to subnational and transnational actors. People will increasingly define their relationships and identities outside the realms of national governments. Transnational social groups based on common values, interests, joint work, economic and friendly ties will form faster. In this case, dual/multiple citizenship will spread rapidly and serve as one of the mechanisms for strengthening a new type of regional community. The blurred political map of the post-Soviet space, where the place of birth and residence do not necessarily coincide with one's citizenship, will be viewed by most countries of the region as a positive phenomenon. All may realize that dual/multiple nationality is better for peace and security than the old system of well-defined 
states with clearly drawn borders, which emerged in Europe from bloody wars and allowed only single citizenship. Borders between states will become less important due to the free movement of people who will call not just one, but two or even several countries their home. The old Westphalian system, which prioritizes nation-states, can gradually be replaced by a structure with an emphasis on free citizens with multiple, flexible and changing national identities. The implementation of the third scenario in the post-Soviet space would require the resolution of conflicts, a high level of regional integration, and at least partial democratization. Needless to say, all this looks quite illusory today. The current spread of dual citizenship is a step leading to the implementation of the second scenario, and in the long term, possibly even the third one.

The analysis of dual citizenship as an instrument of Russian politics in the post-Soviet space shows that Moscow has a potentially strong leverage, but its application is facing both domestic concerns and the resistance of neighboring independent states. The wide spread of dual citizenship in the region can contribute to the erosion of political boundaries and hinder efforts to build national identities and nation-states. However, dual/multiple citizenship will continue proliferating across the post-Soviet space. This is a regular process that is developing in line with global trends. Public policy can speed it up or slow it down, but it cannot stop or reverse it. Analysis of the impact of dual citizenship on Russian and post-Soviet domestic processes is beyond the scope of this article, but this is a very promising area for future research.

\section{References}

Agreement, 1994. Soglashenie mezhdu Rossiyskoi Federatsiei i Turkmenistanom ob uregulirovanii voprosov dvoinogo grazhdanstva [Agreement on Dual Citizenship between the Russian Federation and Turkmenistan]. Available at: <http://docs. cntd.ru/document/1900428> [Accessed 7 March 2021].

Allison, G., 1969. Conceptual Models and the Cuban Missile Crisis. The American Political Science Review, 63 (3), pp. 689-718. 
Arraiza, J.-M., 2015. Good Neighbourliness as a Limit to Extraterritorial Citizenship: The Case of Hungary and Slovakia. In: D. Kochenov, E. Basheska, (eds.) Good Neighbourliness in the European Legal Context. Leiden, the Netherlands: Brill Nijhoff, pp.114-135.

Baaren van Der, L., 2020. Comparative Report: Dual Citizenship in the European Union: Trends and Analysis (2010-2020). Available at: <https://cadmus.eui.eu/ bitstream/handle/1814/67854/RSCAS_2020_04.pdf?sequence=1\&isAllowed=y $>$ [Accessed 7 March 2021].

Bill, 2020. O vnesenii izmeneniy v Federal'ny zakon 'O grazhdanstve Rossiyskoi Federatsii' $v$ chasti uproscheniya protsedury priyoma v grazhdanstovo Rossiyskoi Federatsii inostrannyh grazhdan i lits bez grazhdanstva [On Changes in the Federal Law 'On Citizenship of the Russian Federation' Pertaining to Simplifying Naturalization]. Available at: <https://sozd.duma.gov.ru/bill/938282-7> [Accessed 7 March 2021].

Brubaker, R. and Kim, J., 2011. Transborder Membership Politics in Germany and Korea. European Journal of Sociology, 52(1), pp. 1-17.

Decree, 2019. O vnesenii izmeneniy v Ukaz Prezidenta Rossiyskoi Federatsii ot 29 aprelya 2019 g. $N 187$ [On Changes in the President's Decree, 29 April 2019 \#187]. Available at: <http://static.kremlin.ru/media/events/files/ru/P5fha7h9zo a512JrLlB2bzAmGe55YESz.pdf> [Accessed 7 March 2021].

Dmitriev I., 2006. Pervym delom ekonomika. [The Economy Comes First]. Rossiiskaya gazeta, 5 December [online]. Available at: <https://rg.ru/2006/12/05/ medvedev-smi.html> [Accessed 7 March 2021].

Ganohariti, R., 2020. Dual Citizenship in De Facto States: Comparative Case Study of Abkhazia and Transnistria. Nationalities Papers, 48(1), January, pp.175-192.

Gulina, O., 2020. Rossiya v poiske novyh grazhdan [Russia in Search of New Citizens]. Riddle, 2 June [online]. Available at $<$ https://www.ridl.io/ru/rossijav-poiske-novyh-grazhdan/> [Accessed 7 March 2021].

Harpaz, Y., 2019. Citizenship 2.0: Dual Nationality as a Global Asset. Princeton, New Jersey: Princeton University Press.

Ikenberry, J., 1993. Creating Yesterday's New World Order: Keynsian 'New Thinking' and the Anglo-American Postwar Settlement. In: J. Goldstein and R. Keohane (eds.). Ideas \& Foreign Policy: Beliefs, Institutions, and Political Change. Ithaca, NY: Cornell University Press, pp.57-86. 
International Organization for Migration, 2020. World Migration Report. Geneva: IOM.

Joppke, C., 2003. Citizenship between De- and Re-Ethnicization. European Journal of Sociology, 44 (3), pp.429-458.

Joppke, C., 2010. Citizenship and Immigration. Cambridge, UK: Polity Press.

Kivisto, P., 2007. Conclusion: The Boundaries of Citizenship in a Transnational Age. In: T. Faist and P. Kivisto (eds.). Dual Citizenship in Global Perspective: From Unitary to Multiple Citizenship. New York, NY: Palgrave Macmillan.

Knott, E., 2018. Strategy, Identity or Legitimacy? Analyzing Engagement with Dual Citizenship from the Bottom-Up. Journal of Ethnic and Migration Studies, 45(6), pp. 994-1014.

Kochenov, D., 2021. Grazhdanstvo [Citizenship]. Moscow: Bombora.

Kommersant, 2021. U ukraintsev poishchut vtoroe grazhdanstvo [Ukrainians Will Be Checked for Second Citizenship]. Kommersant, 26 February [online]. Available at: <https://www.kommersant.ru/doc/4710233> [Accessed 7 March 2021].

Kozyrev, A., 1995. Preobrazhenie [Transfiguration]. Moscow: Mezhdunarodnye otnosheniya.

Law, 2002. Federal'ny zakon ot 31.05.2002 g. № 62-FZ 'O grazhdanstve Rossiyskoi Federatsii [Federal Law №\#62-FZ as of 31 May 2002 'On Citizenship of the Russian Federation]. Available at: <http://base.garant.ru/3960484/4d6cc5b823 5f826b2c67847b967f8695/\#block_13> [Accessed 7 March 2021].

Law, 2014. Federalny zakon ot 4 iyunya 2014 g. № 142-FZ 'O vnesenii izmemeniy $v$ statyi 6 i 30 Federalnogo zakona 'O grazhdanstve Rossiyskoi Federatsii' [Federal Law \#142-FZ 'On Amendments to Articles 6 and 30 of the Federal Law 'On Citizenship of the Russian Federation.']. Available at: <https://rg.ru/2014/06/06/ grajdanstvo-dok.html> [Accessed 7 March 2021].

Law, 2017. Federalny zakon $O$ vnesenii izmeneniy $v$ Federalny zakon ' $O$ grazhdanstve Rossiyskoi Federatsii' $i$ stat'yi 8 i 14 Federalnogo zakona 'O pravovom polozhenii inostrannyh grazhdan v Rossiyskoi Federatsii,' 29 iyulya $2017 \mathrm{~g}$. [Federal Law on Amendments to the Federal Law 'On Citizenship of the Russian Federation and Articles 8 and 14 of the Federal Law 'On the Legal Status of Foreign Citizens in the Russian Federation' as of 29 July 2017]. Available at: <http://static.kremlin.ru/media/acts/files/0001201707300049.pdf > [Accessed 7 March 2021]. 
Law, 2020. Federalny zakon ot 24.04.2020 N 134-FZ 'O grazhdanstve Rossiyskoi Federatsii' $v$ chasti uproscheniya protsedury priyoma $v$ grazhdanstvo Rossiyskoi Federatsii inostrannyh grazhdan i lits bez grazhdanstva' [Federal Law \# 134-FZ as of 24 April 2020 'On Citizenship of the Russian Federation' Pertaining to Simplifying Naturalization]. Available at: $<$ http://publication.pravo.gov.ru/ Document/View/0001202004240038> [Accessed 7 March 2021, 2021].

Melvin, N., 2020. Russia’s Policy of Passport Proliferation. Commentary, 1 May. Available at: <https://rusi.org/commentary/russias-policy-passportproliferation $>$ [Accessed 7 March 2021].

Migration, 2021. Central Asian Migration to Russia: Legalization in 2020. Voices on Central Asia, 18 February. Available at: <https://voicesoncentralasia.org/centralasian-migration-to-russia-legalization-in-2020/> [Accessed 7 March 2021].

Milanovic, B., 2016. Global Inequality: A New Approach for the Age of Globalization. Cambridge, Massachusetts: Harvard University Press.

Molodikova, I., 2017. The Transformation of Russian Citizenship Policy in the Context of European or Eurasian Choice: Regional Prospects. Central and Eastern European Migration, 6(1), pp.98-119.

Moscow Times, 2019. Ukraine's Zelenskiy Simplifies Citizenship Process for 'Persecuted' Russians. Moscow Times, 13 August. [online]. Available at: $<$ https://www.themoscowtimes.com/2019/08/13/ukraines-zelenskiy-simplifiescitizenship-process-for-persecuted-russians-a66832> [Accessed 7 March 2021].

Ong, A., 1999. Flexible Citizenship: The Cultural Logic of Transnationality. Durham, North Carolina: Duke University Press.

President of Russia, 2018. Executive Order on Russia's State Migration Policy Concept for 2019-2025. [online]. Available at: <http://en.kremlin.ru/events/ president/news/58986> [Accessed 7 March 2021].

President of Russia, 2019a. Answer to a Journalist's Question after the Ceremony for Presenting the Hero of Labor Medals. 29 April. Available at: <http:// en.kremlin.ru/events/president/news/60412> [Accessed 7 March 2021].

President of Russia, 2019b. Executive Order Identifying Groups of Persons Entitled to a Fast-Track Procedure when Applying for Russian Citizenship on Humanitarian Grounds. Available at: < http://en.kremlin.ru/acts/news/60358> [Accessed 7 March 2021].

President of Russia, 2019c. Vladimir Putin's Annual News Conference, 19 December. Available at: <http://en.kremlin.ru/events/president/news/62366> [Accessed 7 March 2021]. 
Remizov, M., 2016. Russkie i gosudarstvo: natsional'naya ideya do i posle 'Krymskoi vesny' [Russians and the State: National Idea Before and After the 'Crimean Spring']. Moscow: Eksmo.

Republikon Institute, 2014. Hungarian Elections 2014: Turnout and the Impact of the Electoral System. Available at: <http://4liberty.eu/republikon-instituteelection-2014-turnout-and-the-impact-of-the-electoral-system/> [Accessed 1 March 2021].

Shachar, A., 2009. The Birthright Lottery: Citizenship and Global Inequality. Cambridge, Massachusetts: Harvard University Press.

Shachar, A., 2020. Beyond Open and Closed Borders: The Grand Transformation of Citizenship. Jurisprudence, 11(1), pp.1-27. Available at: <https://www.tandfonline. com/doi/full/10.1080/20403313.2020.1788283> [Accessed March 2, 2021].

Shevel, O., 2009. The Politics of Citizenship Policy in New States. Comparative Politics, 41(3), April, pp.273-291.

Shevel, O., 2012. Between Identity and Realpolitik: Citizenship Policy Dilemmas in Post-Soviet Russia. Post-Soviet Affairs, 28(1), January-March, pp.1-37.

Shevel, O., 2017. Citizenship and State Transition. In: A. Shachar, R. Bauböck, I. Bloemraad, and M. Vink (eds.). Oxford Handbook of Citizenship. Oxford: Oxford University Press.

Spiro, P., 2008. Beyond Citizenship: American Identity after Globalization. NY: Oxford University Press.

Spiro, P., 2010. Dual Citizenship as Human Right. International Journal of Constitution Law, 8(1), pp.111-130. Available at: <https://doi.org/10.1093/icon/ mop035> [Accessed 7 March 2021].

Spiro, P., 2016. At Home in Two Countries: The Past and Future of Dual Citizenship. NY: New York University Press.

State Duma, 2020. Zakonoproekt No. 1065287-7 [Bill \#1065287-7]. Available at: <https://sozd.duma.gov.ru/bill/1065287-7> [Accessed 7 March 2021].

TASS, 2021. Rossiya ne voidyot v chislo stran, s kotorymi Ukraina razreshit dvoinoye grazhdanstvo [Russia Will Not Be in the List of Countries with Which Ukraine Will Allow Dual Citizenship]. TASS, 5 March [online]. Available at: $<$ https://tass.ru/mezhdunarodnaya-panorama/1084380> [Accessed 7 March 2021]. Treaty, 1996. Dogovor mezhdu Rossiyskoi Federatsiei i Respublikoi Tadzhikistan ob uregulirovanii voprosov dvoinogo grazhdanstva [Agreement on Dual Citizenship 
Arrangement between the Russian Federation and the Republic of Tajikistan]. Available at: http://docs.cntd.ru/document/8311276 [Accessed 7 March 2021].

Treaty, 1999. Dogovor o druzhbe, sotrudnichestve i partnerstve mezhdu Rossiyskoi Federatsiei i Ukrainoi [Treaty on Friendship, Cooperation, and Partnership between the Russian Federation and Ukraine]. Available at: $<$ http://docs.cntd. $\mathrm{ru}$ /document/1902220> [Accessed 7 March 2021].

Vink, M., De Groot, G.-R., and Luk, N.C., 2020. MACIMIDE Global Expatriate Dual Citizenship Dataset. doi:10.7910/DVN/TTMZ08, Harvard Dataverse, Vol. 5. Available at: <https://macimide.maastrichtuniversity.nl/dual-citdatabase/> [Accessed 7 March 2021].

Waterbury, M., 2014. Making Citizens Beyond the Borders. Nonresident Ethnic Citizenship in Post-Communist Europe. Problems of Post-Communism, 61 (4), pp.36-49.

Yakunin, I., 2020. Deputat Konstantin Zatulin: v Rossiyu edut potomu chto my privlekatelny [Duma Deputy Konstantin Zatulin: People Move to Russia because We Are Attractive]. Komsomolskaya Pravda, 19 March [online]. Available at: <https://www.kp.ru/daily/27132/4219976/> [Accessed 7 March 2021].

Zamakhina, T., 2021. Sluzhi odnoi strane. Deputaty odobrili zapret vtorogo grazhdanstva dlya chinovnikov [Serve One Country. Deputies Approved the Ban on Second Citizenship for Officials]. Rossiyskaya gazeta, 20 January [online]. Available at: <https://rg.ru/2021/01/20/gosduma-odobrila-zapretvtorogo-grazhdanstva-dlia-chinovnikov.html> [Accessed 7 March 2021].

Zelensky, 2019. [Facebook]. 27 April. Available at: <https://m.facebook.com/ story.php?story_fbid $=2236347569948940 \& \mathrm{id}=100007211555008=>$ [Accessed 7 March 2021].

Zevelev, I., 2008. Sootechesvenniki v politike Rossii na postsovetskom prostranstve: imperskoye naslediye i gosudarstvenny pragmatism [Compatriots in Russia's Policy in the Post-Soviet Space: Imperial Legacy and State Pragmatism]. In: A. Miller (ed.) Nasledie imperii i budustchee Rossii [Imperial Legacy and Russian Future]. Moscow: NLO.

Zevelev, I., 2020. New Russian Policy toward Ukraine: Citizenship beyond the Borders. Kennan Cable, 54 (July). Available at: <https://www.wilsoncenter.org/ sites/default/files/media/uploads/documents/KI_200706_cable\%2054_v1.pdf> [Accessed 7 March 2021]. 
Zeveleva, O., 2013. Repatriatsiya i natsional'naya identichnost': opyt Rossii $i$ Germanii [Repatriation and National Identity: Russian and German Experiences]. In: Rossiya i Germaniya v prostranstve evropeiskih kommunikatsy [Russia and Germany in the European Communication Space]. Tyumen: Izdatel'stvo Tyumenskogo Gosudarstvennogo universiteta, pp.246-263. Available at: <https://publications.hse.ru/chapters/109977478> [Accessed 7 March 2021]. Zyuganov, 2020. Russky sterzhen Derzhavy. Statya-manifest Predsedatelya TsK KPRF G.A. Zyuganova [Russian Core of the Great Power: Article-Manifesto by the CPRF Central Committee Chairman G.A. Zyuganov]. Available at: <https:// kprf.ru/party-live/cknews/194458.html> [Accessed 7 March 2021]. 